\title{
Invasion by Austroeupatorium inulifolium (Asteraceae) arrests succession following tea cultivation in the highlands of Sri Lanka
}

\author{
Rohan S. Pethiyagoda ${ }^{1 *}$ and Sudath Nanayakkara ${ }^{2}$ \\ ${ }^{1}$ Churchill College, University of Cambridge, Cambridge CB3 ODS, United Kingdom \\ ${ }^{2}$ The Totum, Agra-Elbedde, Agrapatana, Sri Lanka \\ Accepted 30 November 2011
}

\begin{abstract}
An understanding of floral succession is vital in planning the restoration of native vegetation in abandoned agricultural landscapes. Although such restoration is essential for the establishment of habitat corridors between the fragments of tropical montane cloud forest in the Sri Lankan highlands, in which $>90 \%$ of the land has been converted to tea plantations, no studies of succession have hitherto been possible because of the near-total absence of secondary forest in this region. In a pioneering restoration initiative in 1998, however, tea cultivation was abandoned on a 25 ha site (elevation 1540-1780 m) at Agrapatana, 500 m from a natural forest. Succession was allowed to proceed without intervention, except that tea was removed from 10 ha. By 2009, the invasive Neotropical shrub Austroeupatorium inulifolium and

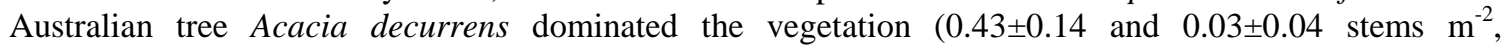
respectively), to the total exclusion of native woody species. There was no significant difference in the density of Austroeupatorium $(82 \pm 12 \%)$ and Acacia $(14 \pm 9 \%)$ between quadrats with and without tea. Methods to suppress these two aggressive invasive species are urgently needed, especially given that Austroeupatorium has recently become established within pristine montane forests such as Horton Plains National Park (2,100 m elevation).
\end{abstract}

Key words: Acacia decurrens, Eupatorium, montane cloud forest, invasive species

\section{INTRODUCTION}

Sri Lanka $\left(65,000 \mathrm{~km}^{2}\right)$ is part of a Global Biodiversity Hotspot (Mittermeier et al., 2004). Some 977 vascular-plant species and 278 vertebrate species are endemic to it (Green et al., 2009). Much of this diversity is concentrated in the tropical montane cloud forests (TMCFs) of the island's central hills, which rise to $2,524 \mathrm{~m}$. With extensive deforestation for planting of tea (Camellia sinensis, F.Theaceae) during the 19th century, the area of TMCF has declined to about $300 \mathrm{~km}^{2}$, approximately $10 \%$ of its pre-colonial extent (Werner, 1995, 2001). TMCF now persists in the form of 18 discrete fragments within a landscape dominated by tea (Forestry Planning Unit 1995). The establishment of habitat connectivity between these forest fragments, through the restoration of native forest vegetation, is considered a high priority for the conservation of Sri Lanka's montane biodiversity (Wikramanayake and Gunatilleke, 2002).

The first step in the establishment of such corridors must be the abandonment of tea cultivation between existing montane-forest fragments. The high economic value of this land $\left(\sim 15,000 \mathrm{ha}^{-1}\right)$, however, has hitherto precluded substantial tracts from becoming available for conversion to secondary forest, and consequently the extent of montane secondary forest in the Sri Lankan highlands remains negligible (Perera, 2001).

An exception has been The Totum at Agrapathana, a 25 ha tea plantation at 1540$1780 \mathrm{~m}$ above sea level established ca 1890 on which, in a pioneering restoration initiative, tea cultivation was aban-doned in 1998. Tea trees were uprooted from an area totaling 10 ha but retained in a further 10 ha, and succession allowed to proceed without further intervention.

Natural-forest succession following acute degradation at such sites at similar elevations elsewhere in the tropics (Sarmiento, 1997; Slocum et al., 2004) or at lower elevations in Sri Lanka (Cohen et al., 2006; Gunaratne et al., 2010) is sometimes arrested by a dense growth of grasses and/or ferns. At The Totum, however, by 2009 succession by native woody pioneers had been entirely thwarted by the aggressive alien species Austroeupatorium inulifolium (Asteraceae, a Neotropical shrub) and-to a lesser extent-Acacia decurrens (Fabaceae, an Australian tree) (Fig. 1).

$\overline{\text { *Corresponding author's email: sarith21@gmail.com }}$ 


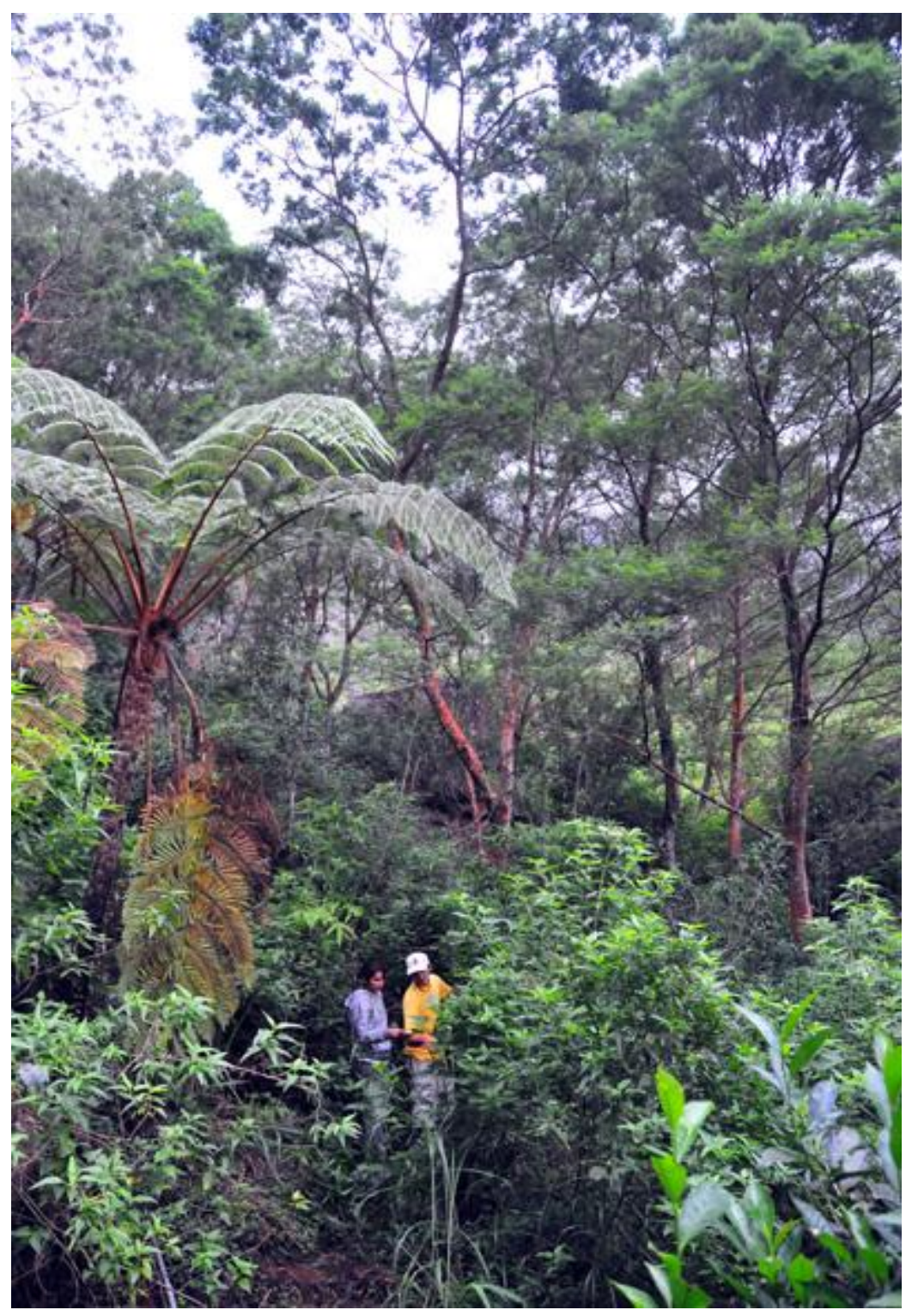

Figure 1. Secondary vegetation at the study site at Agrapatana, Sri Lanka, comprising of a dense growth of the exotic shrub Austroeupatorium inulifolium interspersed with the wattle tree Acacia decurrens; the tree fern Cyathea crinita (left) and tea, Camellia sinensis (bottom right).

While both these species had previously been recorded as naturalized in Sri Lanka (Dassanayake and Fosberg, 1980-2006), neither has hitherto been reported to be invasive. Here, in addition to describing a successional vegetation dominated by Austroeupatorium and Acacia at the study site 11 years after the abandonment of tea cultivation, we show that the retention or removal of tea does not result in significantly different successional outcomes. We also draw attention to the rapid invasion by Austroeupatorium of extensive tracts of hitherto undisturbed montane forests in Sri Lanka.

\section{MATERIAL AND METHODS}

\section{Study area}

The Totum is a 25 ha property $\left(06^{\circ} 50^{\prime} \mathrm{N}, 80^{\circ}\right.$ $\left.40^{\prime} \mathrm{E}\right)$ located on a NE-facing hillside. Rainfall $\left(\sim 2,000 \mathrm{~mm} \mathrm{y}^{-1}\right)$ in the area, which is frequently enveloped in mist, is a seasonally distributed ( 220 rainy days per year), except for a dry season in February-March. By 1998, heavy erosion resulting from a century of poor slopingland management (Hewawasam et al., 2003) had resulted in almost all topsoil being lost and the ultisolic subsoil being exposed. 
The Agrabopath TMCF lies southeast and southwest of The Totum, separated from it by a strip of tea about $300 \mathrm{~m}$ wide. The following tree species are predominant in its canopy and subcanopy: Calophyllum walkeri (Clusiaceae), Syzygium revolutum (Myrtaceae), Symplocos cochin-sinensis (Symplocaceae), Neolitsea fuscata, Cinnamomum ovalifolium and Actinodaphne speciosa (Lauraceae). Strobilanthes (Acanthaceae) shrubs are ubiquitous in the understorey, among which are interspersed dense stands of the bamboo, Arundinaria debilis. An unpublished inventory of the flora of Agrabopath in 2000 by C.N. Karunatilake and A.J. Wijeratne, voucher specimens of which are preserved in The Totum's herbarium, lists 51 species of trees and shrubs with 21 endemics and in addition 44 herbaceous plants with 11 endemics (Table 1). By comparison, Balasubramaniam et al. (1993) found that $50 \%$ of woody species sampled in the TMCF of Horton Plains (2100 $\mathrm{mm}$ asl), about $15 \mathrm{~km}$ from Agrabopath, were endemic.

\section{Sampling}

In July-August 2009 the vegetation in the study site was censused in $32(10 \times 10 \mathrm{~m})$ quadrats approximately $100 \mathrm{~m}$ inside of the site's boundary and equidistant from Agrabopath, the nearest native-plant seed source. Sixteen quadrats were in the area in which tea was removed in 1998, and the other sixteen in areas in which tea was retained, but unharvested. No intervention took place in or near each 'treatment'. All woody plants and tree ferns (considered 'trees' in the analysis) $>1 \mathrm{~m}$ tall were counted and identified against the herbarium, verified using the literature (Dassanayake and Fosberg, 1980-2006); herbaceous plants $>1 \mathrm{~m}$ were inventoried but not counted.

\section{Statistical analysis}

Only woody species and tree ferns were included in the analyses (Table 2). Species diversity (Simpson's Diversity Index, D) and relative density of Austroeupatorium and Acacia were calculated for each quadrat. Data were arcsine transformed to fulfill assumptions of normality. To compare the successional vegetation in the two treatments, analyses of variance were performed to test for differences in species diversity, and the relative density of Austroeupatorium and Acacia in quadrats with and without tea.
Table 1. Trees, tree-shrubs and shrubs recorded from Agrabopath Tropical Montane Cloud Forest reserve, Sri Lanka. *Endemic species.

\begin{tabular}{|c|c|}
\hline Family & Species \\
\hline Acanthaceae & $\begin{array}{l}\text { Strobilanthes nockii }{ }^{*} \\
\text { Strobilanthes sexennis }\end{array}$ \\
\hline Apocynaceae & Rauvolfia densiflora \\
\hline Aquifoliaceae & Ilex walkeri \\
\hline Asteraceae & $\begin{array}{l}\text { Anaphalis pelliculata* } \\
\text { Vernonia setigera* } \\
\text { Vernonia wightiana* }\end{array}$ \\
\hline Celastraciacae & $\begin{array}{l}\text { Euonymus revolutus* } \\
\text { Microtropis zeylanica* }\end{array}$ \\
\hline Clusiaceae & $\begin{array}{l}\text { Calophyllum walkeri* } \\
\text { Garcinia echinocarpa }\end{array}$ \\
\hline Cyathiaceae & $\begin{array}{l}\text { Cyathea crinita* } \\
\text { Cyathea walkerae* }\end{array}$ \\
\hline Dilleniaceae & Schumacheria alnifolia* \\
\hline Ericaceae & Vaccinium leschenaulti \\
\hline Euphorbiaceae & $\begin{array}{l}\text { Homalanthus populifolius } \\
\text { Macaranga peltata }\end{array}$ \\
\hline Flacourtiaceae & Casearia thwaitesii \\
\hline Lauraceae & $\begin{array}{l}\text { Actinodaphne speciosa* } \\
\text { Actinodaphne molochina } \\
\text { Cinnamomum ovalifolium } \\
\text { Neolitsea fuscata }\end{array}$ \\
\hline Liliaceae & Asparagus gonoclados \\
\hline Melastomataceae & Memecylon parvifolium* \\
\hline Myrsinaceae & $\begin{array}{l}\text { Ardisia gardneri* } \\
\text { Ardisia wightiana* } \\
\text { Maesa indica }\end{array}$ \\
\hline Myrtaceae & $\begin{array}{l}\text { Rhodomyrtus tomentosa } \\
\text { Syzygium revolutum }\end{array}$ \\
\hline Oxalidaceae & Biophytum proliferum \\
\hline Rosaceae & $\begin{array}{l}\text { Rubus ellipticus } \\
\text { Rubus leucocarpus* } \\
\text { Rubus rugosus } \\
\text { Prunus ceylanica }\end{array}$ \\
\hline Rubiaceae & $\begin{array}{l}\text { Lasianthus gardneri } \\
\text { Psychotria sarmentosa } \\
\text { Psychotria nigra* }\end{array}$ \\
\hline Rutaceae & $\begin{array}{l}\text { Acronychia pedunculata } \\
\text { Euodia lunu-ankenda }\end{array}$ \\
\hline Sabiaceae & Meliosma pinnata \\
\hline Sapotaceae & $\begin{array}{l}\text { Isonandra compta* } \\
\text { Palaquium rubiginosum* }\end{array}$ \\
\hline Smilacaceae & Smilax zeylanica \\
\hline Staphyleacae & Turpinia malabarica \\
\hline Symplocaceae & $\begin{array}{l}\text { Symplocos bractialis* } \\
\text { Symplocos cochinchinensis } \\
\text { Symplocos elegans var. } \\
\text { minor* }\end{array}$ \\
\hline Theaceae & $\begin{array}{l}\text { Symplocos obtusa } \\
\text { Eurya chinensis } \\
\text { Gordonia ceylanica* }\end{array}$ \\
\hline Urticaceae & Pilea angulata \\
\hline
\end{tabular}


Table 2. Identity, status, habit and mean density ( \pm s.d.) of plant stems $>1 \mathrm{~m}$ high (in $10 \times 10 \mathrm{~m}$ quadrats) (a) with tea removed and (b) with tea retained in the Totum.. *Endemic species

\begin{tabular}{|c|c|c|c|c|}
\hline \multirow{2}{*}{$\begin{array}{l}\text { Species } \\
\text { Woody }\end{array}$} & \multirow[t]{2}{*}{ Status } & \multirow[t]{2}{*}{ Habit } & \multicolumn{2}{|c|}{ Mean density $\left(\right.$ stems $\left.\mathrm{m}^{-2} \times 100\right)$} \\
\hline & & & (a) & (b) \\
\hline Austroeupatorium inulifolium & exotic & Shrub & $42.5 \pm 18.1$ & $42.7 \pm 8.69$ \\
\hline Camellia sinensis & exotic & Tree & $0.00 \pm 0.00$ & $8.06 \pm 4.39$ \\
\hline Acacia decurrens & exotic & Tree & $3.38 \pm 4.29$ & $3.25 \pm 4.18$ \\
\hline Cyathea crinita* & native & tree' & $0.18 \pm 0.54$ & $0.69 \pm 1.25$ \\
\hline Cyathea walkeri* & native & tree' & $0.31 \pm 0.60$ & $0.50 \pm 0.97$ \\
\hline Syzygium jambos & exotic & Tree & $0.75 \pm 1.48$ & $0.69 \pm 1.25$ \\
\hline Strobilanthes nockii* & native & Shrub & $0.13 \pm 0.50$ & $0.44 \pm 0.96$ \\
\hline Rubus ellipticus & native & Shrub & $0.38 \pm 0.62$ & $0.50 \pm 0.89$ \\
\hline \multicolumn{5}{|l|}{ Herbaceous } \\
\hline Cymbopogon nadus & exotic & Grass & $9.38 \pm 11.5$ & $6.19 \pm 8.82$ \\
\hline Smilax perfoliata & native & Climber & $0.27 \pm 0.46$ & $0.31 \pm 0.70$ \\
\hline Dicranopteris linearis & native & Fern & $0.13 \pm 0.50$ & $0.44 \pm 1.50$ \\
\hline Osbekia rubicunda* & native & Herb & $0.25 \pm 1.00$ & $0.19 \pm 0.50$ \\
\hline Tripsacum laxum & exotic & Grass & $2.13 \pm 3.81$ & $5.06 \pm 8.83$ \\
\hline Pteridium aquilinum & native & Fern & $0.44 \pm 1.50$ & $0.31 \pm 1.00$ \\
\hline Tephrosia vogelii & exotic & Herb & $0.00 \pm 0.00$ & $0.38 \pm 0.86$ \\
\hline
\end{tabular}

Additionally, to test for any effect Acacia or tea may have on Austroeupatorium independent of each other; four correlation coefficients (Pearson's) were calculated for correlations between the absolute densities of Austroeupatorium and Acacia, in the presence and absence of tea, using data from quadrats containing Acacia but not tea, $(\mathrm{n}=7)$ and those containing both tea and Acacia ( $\mathrm{n}=9$ ); and Austroeupatorium and tea, using data from quadrats containing tea but not Acacia $(\mathrm{n}=8)$, and those containing both tea and Acacia $(\mathrm{n}=8)$.

\section{RESULTS}

A total of 2,078 plants representing 15 species were counted, of which 1,662 (eight species) were woody (i.e. trees or shrubs; Table 2). Austroeupatorium accounted for $82 \pm 12 \%$ of all woody stems, and Acacia (14 $\pm 9 \%)$. There was no significant difference in density of Austroeupatorium $(\mathrm{P}=0.60, \mathrm{n}=32)$ or Acacia $(\mathrm{P}=0.737, \mathrm{n}=32)$ between quadrats in which tea had been retained or removed, and no significant difference in diversity $(\mathrm{P}=0.38, \mathrm{n}=32)$ between these treatments (Fig. 2). There was, however, a negative correlation $(\mathrm{r}=-0.645, \mathrm{n}=7)$ between the absolute density of Austroeupatorium and Acacia in quadrats lacking tea; no other correlations were found $(\mathrm{r}<0.2, \mathrm{n}=8)$.

Austroeupatorium was the dominant species in all treatments, accounting for $76 \pm 10 \%$ of woody stems in quadrats containing tea (tea represented $15 \pm 8 \%$ ) and $87 \pm 12 \%$ in those from which tea had been removed; Acacia accounted for $11 \pm 6 \%$ and $18 \pm 11 \%$, respectively. Only two species of native shrubs (Rubus ellipticus and

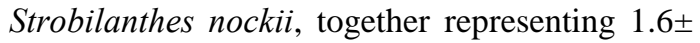
$2.4 \%$ of woody stems were counted), and no native tree species, were recorded (Table 1). 


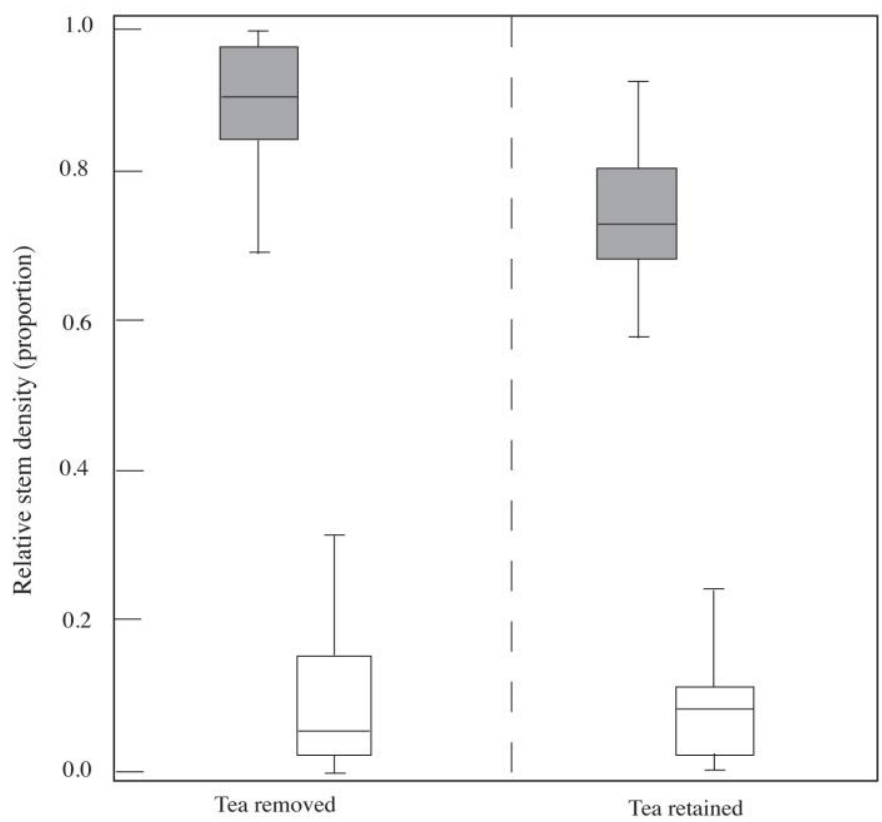

Figure 2. Relative mean density and interquartile ranges of Austroeupatorium (shaded bars) and all native woody plant species (clear bars) with (a) tea removed and (b) tea retained in the Totum. (Error bars indicate interquartile ranges)

\section{DISCUSSION}

Photographs taken between 1998-2000 suggest that $A$. inulifolium became established at the study site within six months of abandonment, with 2-3 m tall Acacia appearing by 2000 . This community appears successfully to have arrested succession by native trees. Although the Agrabopath TMCF, a potential propagule source, is only $300 \mathrm{~m}$ distant from the boundary of The Totum; and despite the abundance at the site of perches and frugivores (e.g., the Yelloweared bulbul Pycnonotus penicillatus, and the Toque macaque Macaca sinica), successful seed dispersal from the forest appears to have been negligible. The only native 'trees' present on the site are the tree ferns Cyathea crinita and $C$. walkeri (Cyatheaceae), which together account for only $2 \%$ of woody stems. The near-total absence of native secondary forest in the highlands (Perera, 2001) makes it impossible to know what the pioneer species may have been before the introduction of numerous exotics during the colonial period.

First recorded from Sri Lanka only in 1980, A. inulifolium has hitherto been considered rare (Grierson, 1980). Though recently recognized as naturalized in Taiwan (Hsu, 2006), the species has previously not been considered invasive in Sri Lanka or South Asia (Gunasekera, 2009). Austroeupatorium, however, is now becoming increasingly common on roadsides and TMCF margins at elevations $>1,500 \mathrm{~m}$ in Sri Lanka. It is of concern that by mid-2009 substantial expanses of it had become established within 'pristine' TMCFs such as Horton Plains National Park (elevation $\sim 2,100 \mathrm{~m}$ ) (Fig. 3), where an intensive survey as recently as 2007 had failed to record it (Department of Wildlife Conservation, 2007).

In acutely degraded tropical montane environments in the Dominican Republic and Ecuador, succession is arrested by herbaceous vegetation comprising grasses and ferns (Perera, 2001; Slocum et al. 2004). In the Sri Lankan lowlands, succession has been found to be arrested by the fern Dicranopteris linearis (Gleicheniaceae) and the grass Imperata cylindrica (Cohen et al., 2006). When these were removed, woody-plant recruitment included eight indigenous tree and shrub species (Cohen et al., 2006). At The Totum, however, the removal of tea made almost no difference to the successional outcome. At a 1,000-m elevation site in Sri Lanka, however, even after $~ 30$ $\mathrm{y}$ of abandonment of tea, succession was arrested by Cymbopogon nardus grass, with woody-plant seedling emergence $<0.1 \mathrm{~m}^{-2} \mathrm{y}^{-1}$, less than a sixtieth of that in neighboring natural forest (Gunaratne et al., 2010). While C. nardus is present at low densities in The Totum, it is clearly outcompeted by Austroeupatorium. 


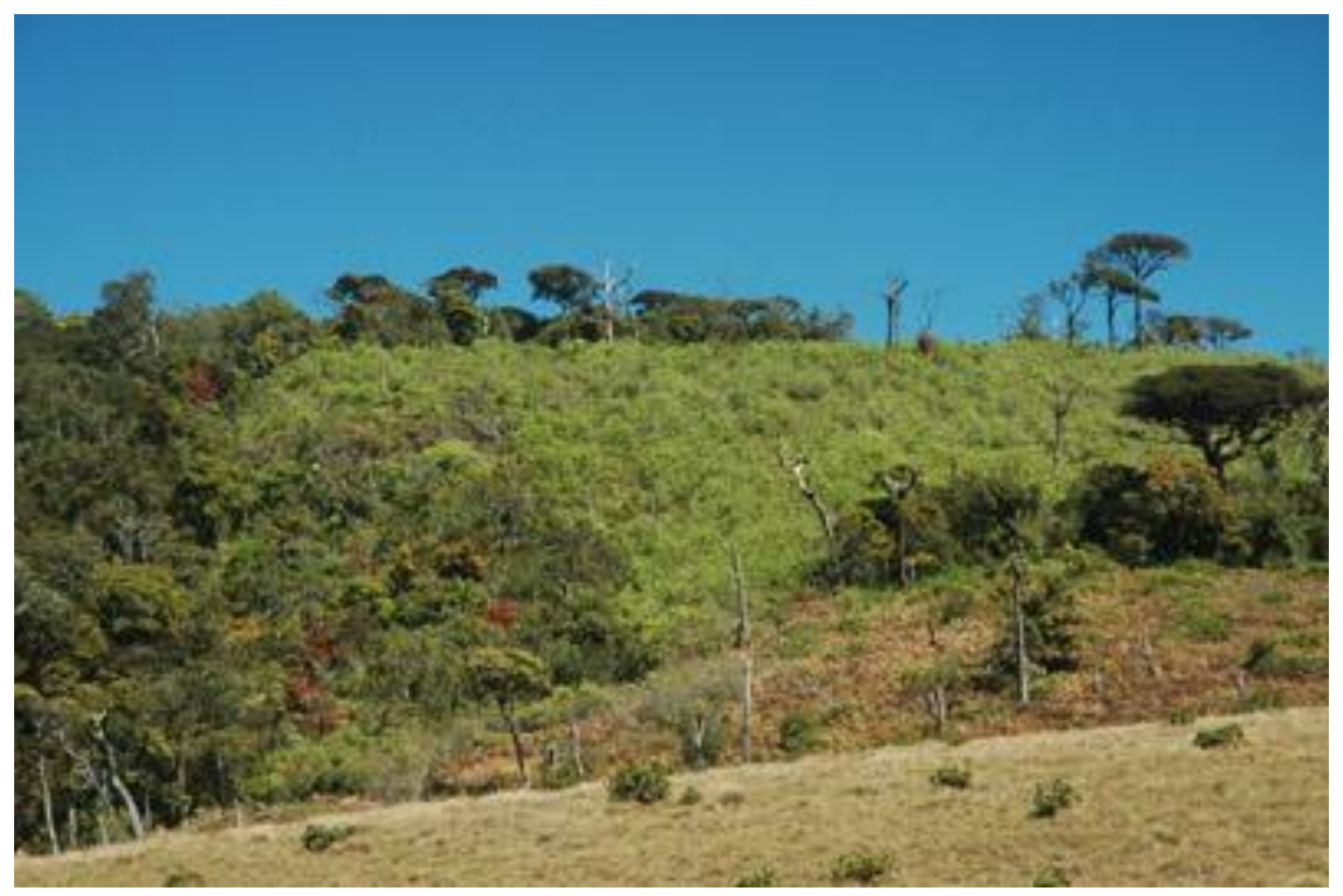

Figure 3. An expanse of Austroeupatorium inulifolium in Horton Plains National Park (2,100m a.s.1.), a pristine tropical montane cloud forest in central Sri Lanka, apparently replacing bracken (Pteridium aquilinum, darker brown area mid-right) that had previously arrested succession following a fire in 1989.

The restoration of native secondary forest in the Sri Lankan highlands is unlikely to be successful unless means of suppressing Austroeupatorium and Acacia are developed. While the latter could possibly be controlled by harvesting for timber or firewood, the former, like its relative Chromolaena odorata at lower elevations, is likely to pose a serious threat to the native montane flora (Sharma et al., 2005) while proving difficult and expensive to eradicate at the landscape level (Honu \& Dang, 2000).

\section{ACKNOWLEDGEMENTS}

We are grateful to the management of The Totum for permission to work at the study site and for hospitality. We also thank Kelum Manamendra-Arachchi for assistance in the field.

\section{REFERENCES}

Cohen, A.L., Singhakumara, B.M.P. and Ashton, P.M.S. (2006). Releasing rain forest succession: a case study in the Dicranopteris linearis fernlands of Sri Lanka. Restoration Ecology 3:261-270.

Dassanayake, M.D. and Fosberg, F.R. (Eds.) 1980-2006. A Revised Handbook to the Flora of Ceylon, vols. 1-15. Oxford \& IBH, New Delhi.

Department of Wildlife Conservation. (2007). Biodiversity baseline survey: Horton Plains National Park. Department of Wildlife Conservation, Ministry of Environment and Natural Resources, Colombo.

Forestry Planning Unit (1995). Sri Lanka forestry sector master plan. Ministry of Agriculture, Lands and Forestry, Battaramulla.

Green, M.J.B., How, R. and Padmalal, U.K.G.K. (2009). The importance of monitoring biological diversity and its application to Sri Lanka. Tropical Ecology 50:41-56.

Grierson, A.J.C. (1980). Compositae. Pp. 111278 in Dassanayake, M.D. and Fosberg, F.R. (Eds.) A Revised Handbook to the Flora of Ceylon, vol. 1. Oxford \& IBH, New Delhi.

Gunaratne, A.M.T.A., Gunatilleke, C.V.S. and Gunatilleke, I.A.U.N. (2010). Barriers to tree seedling emergence on human-induced grasslands in Sri Lanka. Journal of Applied Ecology 47:157-165. 
Gunasekera, L. (2009). Invasive plants: a guide to the identification of the most invasive plants in Sri Lanka. Print and Print Graphics (Pvt) Ltd., Colombo.

Hewawasam, T., von Blanckenburg, F., Schaller, M. and Kubik, P. (2003). Increase of human over natural erosion rates in tropical highlands constrained by cosmogenic nuclides. Geology 31:597-600.

Honu, Y.A.K. and Dang, Q.L. (2000). Responses of tree seedlings to the removal of Chromolaena odorata Linn. in a degraded forest in Ghana. Forest Ecology and Management 137:75-82.

Hsu, T.-W., Peng, C.I. and Wang, C.M. (2006). Austroeupatorium inulifolium Kunth, King \& Robinson (Asteraceae), a newly naturalized plant in Taiwan. Taiwania 51:41-45.

Mittermeier, R.A., Hoffman, M. and Pilgrim, J. (2004). Hotspots revised: Earth's biologically richest and most endangered terrestrial ecoregions. Conservation International, Washington DC.

Perera, G.A.D. (2001). The secondary forest situation in Sri Lanka: a review. Journal of Tropical Forest Science 13:768-785.
Sarmiento, F.O. (1997). Arrested succession in pastures hinders regeneration of Tropandean forests and shreds mountain landscapes. Environmental Conservation 24:14-23.

Sharma, G.P., Singh, J.S. and Raghubanshi, A.S. (2005). Plant invasions: Emerging trends and future implications. Current Science 88:726734.

Slocum, M.G., Aide, T.M. and Zimmerman, J.K. (2004). Natural regeneration of subtropical montane forest after clearing fern thickets in the Dominican Republic. Journal of Tropical Ecology, 20:483-486.

Werner, W.L. (1995). Biogeography and ecology of upper montane rain forest of Sri Lanka (Ceylon). Pp. 343-352 in Hamilton, S.L. et al. (Eds.) Tropical Montane Cloud Forests. Springer-Verlag, New York.

Werner, W. (2001). Sri Lanka's magnificent cloud forests. WHT Publications, Colombo.

Wikramanayake, E.D. and Gunatilleke, S. (2002). Sri Lanka's montane rain forests. Pp. 290-293 in Wikramanayake ED et al. (Eds.) Terrestrial Ecoregions of the Indo-Pacific: A Conservation Assessment. Island Press, Washington DC. 